\title{
GAYA KOMUNIKASI MASYARAKAT PESISIR WEDUNG JAWA TENGAH
}

\author{
Mahfudlah Fajrie \\ Dosen Fakultas Dakwah dan Komunikasi UNISNU Jepara \\ mahfudlahfajrie@gmail.com
}

\begin{abstract}
The coastal communities put human on equality. Therefore, Wedung district community has its own communication style in delivering opinions and social interaction interpersonally. This article is the result of field research study with an ethnographic approach and analysis of cultural themes. The aim is to determine the communication style of coastal communities when communicating with outside communities of coastal areas and tourists. The results show that the communication style of coastal communities in communicating with other people and the community outside of coastal areas is the equalitarian and the relinguishing styles. It means that the coastal communities have the nature of open communication and receptive to suggestions and opinions of others.
\end{abstract}

Keywords: style, communication, community, coastal

\begin{abstract}
Abstrak
Masyarakat pesisir menempatkan manusia pada tingkat kesetaraan. Oleh sebab itu, masyarakat Kecamatan Wedung mempunyai gaya komunikasi sendiri dalam menyampaikan pendapatnya dan berinteraksi sosial dengan masyarakat lain. Artikel ini adalah hasil penelitian field research dengan pendekatan etnografi dan analisis tema kultural. Dengan tujuan untuk mengetahui gaya komunikasi masyarakat pesisir ketika berkomunikasi dengan masyarakat luar wilayah pesisir dan turis (wisatawan). Hasilnya menunjukkan gaya komunikasi masyarakat pesisir dalam berkomunikasi dengan masyarakat lain maupun masyarakat di luar wilayah pesisir adalah the equalitarian style dan the relinguishing style, artinya masyarakat pesisir dalam berkomunikasi mempunyai sifat terbuka dan mau menerima saran serta pendapat dari orang lain.
\end{abstract}

Kata Kunci: Gaya, Komunikasi, Masyarakat, Pesisir 
INJECT: Interdisciplinary Journal of Communication, Vol.2, No.1, Juni 2017: h. 53-76

\section{Pendahuluan}

Indonesia termasuk salah satu negara maritim, disebut demikian karena sebagian besar wilayah Indonesia berupa lautan. Hal inilah yang menjadikan masyarakat Indonesia memanfaatkan dan menggantungkan hidupnya pada sumber hasil laut. Ketergantungan masyarakat terhadap sektor laut memberikan identitas tersendiri sebagai masyarakat pesisir dengan pola hidup yang dikenal sebagai kebudayaan pesisir (Geertz, 1981:42).

Salah satu faktor yang mempengaruhi terbentuknya kebudayaan adalah lingkungan alam fisik seperti situasi dan kondisi yang secara tidak langsung akan membentuk watak kepribadian serta budaya masyarakat yang tinggal di lingkungan itu (Syarif, 2008:65). Berbicara lingkungan alam, Indonesia mempunyai berbagai lingkungan alam dari mulai perkotaan, pedesaan, dan pesisir. Dengan berbagai macam karakteristik alam Indonesia, tentu budaya juga berbeda-beda, baik itu masyarakat kota, desa, dan pesisir mempunyai karakteristik dan kebudayaan yang berbeda pula.

Masyarakat pesisir merupakan suatu kumpulan manusia yang memiliki pola hidup, tingkah laku, dan karakteristik tertentu yang tinggal di wilayah perbatasan antara daratan dan lautan. Masyarakat pesisir cenderung bertahan hidup dan memenuhi kebutuhanya dari sumber hasil laut yakni perikanan, sehingga masyarakat pesisir membentuk budaya sendiri yaitu budaya masyarakat pesisir. Selanjutnya, budaya pesisir juga dapat diartikan sebagai sistem pengetahuan yang berisi konsep, teori, metode, atau teknik yang digunakan untuk melangsungkan dan memenuhi kebutuhan hidupnya baik fisik maupun sosial. Budaya pesisir diantaranya berupa bahasa, seni, kepercayaan, pengetahuan, organisasi sosial (politik), teknologi, dan ekonomi.

Masyarakat pesisir banyak terdapat di beberapa wilayah pesisir di Indonesia, dan antara wilayah satu dengan yang lain juga berbedabeda budayanya. Salah satunya adalah berada di wilayah Kecamatan Wedung Kabupaten Demak Provinsi Jawa Tengah. Kecamatan Wedung 
merupakan salah satu wilayah di Kabupaten Demak yang terletak di pesisir pantai laut Jawa dengan luas wilayah 93.876 ha merupakan 11 persen dari seluruh wilayah di Kabupaten Demak. Oleh karena itu Kecamatan Wedung memiliki luas wilayah paling luas di Kabupaten Demak, dengan jumlah penduduk 80.827 jiwa yang terdiri dari 39.305 laiki-laki dan 41.522 perempuan (BPS Kab. Demak). Masyarakat Kecamatan Wedung mayoritas memenuhi kebutuhan hidupnya bergantung pada hasil laut dan olahannya, seperti pembuat garam, krupuk ikan, pengasapan ikan, terasi dan pengeringan ikan.

Melihat kondisi perekonomian dan sosial masyarakat di Kecamatan Wedung, tentunya tidak lepas dari unsur budaya. Salah satu unsur budaya yang menarik dari masyarakat pesisir Kecamatan Wedung adalah gaya komunikasi terutama dialek dan bahasa yang digunakan dalam berkomunikasi baik dengan sesama masyarakat pesisir, masyarakat lain diluar wilayah pesisir dan turis (wisatawan).

Masyarakat di Kecamatan Wedung termasuk masyarakat yang tinggal di wilayah pesisir, sehingga memiliki kebudayaan pesisiran dan dapat digolongkan sebagai masyarakat yang peradabannya kasar. Hal ini ditandai dengan sikap yang lugas, spontan, tutur kata yang cenderung kasar, tetapi dari segi keagamaan termasuk Islam puritan dan memiliki sikap toleransi yang tinggi.

Corak Islam puritan dan sikap lugasnya mewarnai kepribadian masyarakat pesisir dalam kesehariannya. Sehingga ada ungkapan "katakan yang benar walaupun pahit di dengar". Hal inilah yang terkadang tidak bisa diterima masyarakat luar Kecamatan Wedung, terutama masyarakat jawa seperti di Kecamatan Demak. Karena pada dasarnya masyarakat pesisir menempatkan manusia pada tingkat kesetaraan. Oleh sebab itu, masyarakat Kecamatan Wedung mempunyai gaya komunikasi sendiri dalam menyampaikan pendapatnya dan berinteraksi sosial dengan mayarakat lain. 
Berbicara budaya tentunya sangat luas pengertiannya, namun budaya dalam hal ini lebih dispesifikasikan pada gaya komunikasi meliputi dialek, penggunaan bahasa, sikap, gaya berkomunikasinya. Bagaimanapun setiap masyarakat mempunyai komunitasnya dan di situlah mereka membentuk budaya komunitasnya sendiri.

Oleh sebab itu dengan mengetahui gaya komunikasi masyarakat pesisir maka akan lebih mudah mengetahui karakteristik masyarakat pesisir, sehingga mempermudah dalam pelaksanaan pengembangan dan pemberdayaan baik fisik maupun sumber daya manusia di wilayah pesisir

\section{Permasalahan}

Kebudayaan masyarakat Kecamatan Wedung yang cenderung kasar menjadikan model komunikasi masyarakat pesisir nampak lugas dan spontan, namun terkadang tidak semua masyarakat bisa menerima sikap tersebut. Oleh karena itu, bagaimana jika masyarakat Kecamatan Wedung berkomunikasi dengan masyarakat lain luar wilayah pesisir, maupun turis (wisatawan). Maka rumusan masalah dalam penelitian ini adalah "Bagaimana gaya komunikasi masyarakat pesisir Kecamatan Wedung Kabupaten Demak dalam berkomunikasi dengan sesama masyarakat pesisir Kecamatan Wedung, masyarakat luar wilayah Kecamatan Wedung dan turis (wisatawan).

\section{Budaya dan Unsur-unsur kebudayaan}

Budaya atau kebudayaan berasal dari bahasa sansekerta yaitu buddhayah bentuk jamak dari buddhi (budi atau akal) diartikan sebagai hal-hal yang berkaitan dengan budi dan akal manusia. Menurut bahasa Inggris kebudayaan disebut culture yang berasal dari kata latin colere yaitu mengolah atau mengerjakan terkadang kata culture juga sering diterjemahkan ke dalam bahasa Indonesia sebagai kultur (Muhaimin, 2001: 153). 
Geertz (dalam Tasmuji, 2011:154) mengatakan bahwa budaya adalah suatu sistem makna dan simbol yang disusun dalam pengertian dimana individu-individu mendefinisikan dunianya, menyatakan perasaannya dan memberikan penilaian- penilaiannya, suatu pola makna yang ditransmisikan secara historis, diwujudkan dalam bentuk-bentuk simbolik melalui sarana dimana orang-orang mengkomunikasikan, mengabdikan, dan mengembangkan pengetahuan, karena kebudayaan merupakan suatu sistem simbolik maka haruslah dibaca, diterjemahkan dan diinterpretasikan.

Linton (dalam Tasmuji, 2011:151) memberikan definisi kebudayaan adalah seluruh cara kehidupan dari masyarakat dan tidak hanya mengenai sebagian tata cara hidup saja yang dianggap lebih tinggi dan lebih diinginkan. Guru besar antropologi Indonesia Koentjaraningrat (1993:9) berpendapat bahwa kebudayaan berasal dari kata sansekerta buddhayah bentuk jamak dari buddhi yang berarti budi atau akal, sehingga menurutnya kebudayaan dapat diartikan sebagai hal-hal yang bersangkutan dengan budi dan akal, ada juga yang berpendapat sebagai suatu perkembangan dari majemuk budi-daya yang artinya daya dari budi atau kekuatan dari akal.

Sementara Selo Soemardjan dan Soeleman Soemardi (dalam Ranjabar, 2006:21) merumuskan kebudayaan sebagai semua hasil karya, rasa dan cipta masyarakat. Karya masyarakat menghasilkan teknologi dan kebudayaan kebendaan atau kebudayaan jasmaniah yang diperlukan oleh manusia untuk menguasai alam sekitarnya agar kekuatan serta hasilnya dapat diabadikan untuk keperluan masyarakat. Jadi dapat disimpulkan bahwa kebudayaan, menurut penulis adalah semua hasil karya cipta manusia baik yang berupa benda maupun jasmaniah yang diakui dan masih diabadikan oleh masyarakat.

MenurutKoentjaraningrat(1993:5)bahwa kebudayaan mempunyai tiga unsur, yaitu pertama sebagai suatu ide, gagasan, nilai-nilai, norma- 
norma peraturan dan sebagainya, kedua sebagai suatu aktifitas kelakuan berpola dari manusia dalam sebuah komunitas masyarakat, ketiga bendabenda hasil karya manusia.

Sedangkan menurut pendapat Kluckhon dalam bukunya yang berjudul Universal Categories of Culture membagi kebudayaan yang ditemukan pada semua bangsa di dunia dari sistem kebudayaan yang sederhana seperti masyarakat pedesaan hingga sistem kebudayaan yang kompleks seperti masyarakat perkotaan. Kluckhon membagi sistem kebudayaan menjadi tujuh unsur kebudayaan universal atau disebut dengan kultural universal (Tasmuji, 2011:160-165). Ketujuh unsur kebudayaan tersebut adalah: Pertama, sistem bahasa; Bahasa merupakan sarana bagi manusia untuk memenuhi kebutuhan sosialnya untuk berinteraksi atau berhubungan dengan sesamanya. Dalam ilmu antropologi, studi mengenai bahasa disebut dengan istilah antropologi linguistik. Kemampuan manusia dalam membangun tradisi budaya, menciptakan pemahaman tentang fenomena sosial yang diungkapkan secara simbolik, dan mewariskannya kepada generasi penerusnya sangat bergantung pada bahasa. Dengan demikian, bahasa menduduki porsi yang penting dalam analisa kebudayaan manusia.

Kedua, sistem pengetahuan; Sistem pengetahuan dalam kultural universal berkaitan dengan sistem peralatan hidup dan teknologi karena sistem pengetahuan bersifat abstrak dan berwujud di dalam ide manusia. Sistem pengetahuan sangat luas batasannya karena mencakup pengetahuan manusia tentang berbagai unsur yang digunakan dalam kehidupannya. Banyak suku bangsa yang tidak dapat bertahan hidup apabila mereka tidak mengetahui dengan teliti pada musim-musim apa berbagai jenis ikan pindah ke hulu sungai. Selain itu, manusia tidak dapat membuat alat-alat apabila tidak mengetahui dengan teliti ciri-ciri bahan mentah yang mereka pakai untuk membuat alat-alat tersebut. Setiap kebudayaan selalu mempunyai suatu himpunan pengetahuan tentang alam, 
tumbuh-tumbuhan, binatang, benda, dan manusia yang ada di sekitarnya.

Ketiga, sistem sosial; Unsur budaya berupa sistem kekerabatan dan organisasi sosial merupakan usaha antropologi untuk memahami bagaimana manusia membentuk masyarakat melalui berbagai kelompok sosial.MenurutKoentjaraningrattiapkelompokmasyarakatkehidupannya diatur oleh adat istiadat dan aturan-aturan mengenai berbagai macam kesatuan di dalam lingkungan dimana dia hidup dan bergaul dari hari ke hari. Kesatuan sosial yang paling dekat dan dasar adalah kerabatnya, yaitu keluarga inti yang dekat dan kerabat yang lain. Selanjutnya, manusia akan digolongkan ke dalam tingkatan-tingkatan lokalitas geografis untuk membentuk organisasi sosial dalam kehidupannya.

Keempat, sistem peralatan hidup dan teknologi; Manusia selalu berusaha untuk mempertahankan hidupnya sehingga mereka akan selalu membuat peralatan atau benda-benda penunjang hidup. Perhatian awal para antropolog dalam memahami kebudayaan manusia berdasarkan unsur teknologi yang dipakai suatu masyarakat berupa benda-benda yang dijadikan sebagai peralatan hidup dengan bentuk dan teknologi yang masih sederhana. Dengan demikian, bahasan tentang unsur kebudayaan yang termasuk dalam peralatan hidup dan teknologi merupakan bahasan kebudayaan fisik.

Kelima, sistem mata pencaharian hidup; Mata pencaharian atau aktivitas ekonomi suatu masyarakat menjadi fokus kajian penting etnografi. Mata pencaharian suatu kelompok masyarakat atau sistem perekonomian masyarakat untuk mencukupi kebutuhan hidupnya menjadi unsur kebudayaan karena dari mata pencaharian suatu masyarakat dapat membedakan kebudayaan wilayah tersebut dan tingkat pengetahuan masyarakatnya.

Keenam, sistem religi; Asal mula permasalahan fungsi religi dalam masyarakat adalah adanya pertanyaan mengapa manusia percaya kepada adanya suatu kekuatan gaib atau supranatural yang dianggap lebih tinggi 
daripada manusia dan mengapa manusia itu melakukan berbagai cara untuk berkomunikasi dan mencari hubungan-hubungan dengan kekuatankekuatan supranatural tersebut. Usaha untuk memecahkan pertanyaan mendasar yang menjadi penyebab lahirnya asal mula religi tersebut, para ilmuwan sosial berasumsi bahwa religi suku-suku bangsa yang ada di dunia adalah sisa dari bentuk- bentuk religi kuno yang dianut oleh seluruh umat manusia pada zaman dahulu ketika kebudayaan mereka masih primitif.

Ketujuh, kesenian; Dalam hal ini adalah segala aktivitas kesenian suatu masyarakat tradisional. Bisa berupa benda-benda atau artefak yang memuat unsur seni, seperti patung, ukiran, dan hiasan. Unsur seni pada kebudayaan manusia lebih mengarah pada teknik-teknik dan proses pembuatan benda seni tersebut.

Tokoh antropolog Bronislaw Malinowski (dalam Ranjabar, 2006: 22) berpendapat bahwa ada 4 unsur pokok dalam kebudayaan yang meliputi: (1) sistem norma sosial yang memungkinkan kerja sama antara para anggota masyarakat untuk menyesuaikan diri dengan alam sekelilingnya, (2) organisasi ekonomi, (3) alat-alat dan lembaga atau petugas-petugas untuk pendidikan, (5) organisasi kekuatan politik.

Sementara itu Melville J. Herkovits (dalam Ranjabar, 2006:21) mengatakan bahwa unsur-unsur kebudayaan terangkum dalam empat unsur yaitu alat-alat teknologi, sistem ekonomi, keluarga dan kekuasaan politik.

Berkaitan dengan budaya dan unsur-unsurnya yang bersifat universal. Setiap daerah, wilayah maupun negara mempunyai kebudayaan yang berbeda-beda. Baik dari segi bahasa, pakaian, gaya komunikasi maupun tradisi-tradisi yang sering dilakukan masyarakatnya. Berbedanya kebudayaan dan unsur-unsur budaya yang ada tentu juga dipengaruhi oleh letak geografis suatu wilayah dan sumber daya alam maupun sumber daya manusia dalam wilayah tersebut. 


\section{Gaya Komunikasi Masyarakat Pesisir}

Salah satu yang menjadi fokus penelitian ini adalah gaya komunikasi. maka agar dapat dipahami dan penelitian berlandaskan teori, maka perlu adanya pembahasan tentang gaya komunikasi.

Gaya komunikasi (communication style) didefinisikan sebagai seperangkat perilaku antarpribadi yang terspesialisasi digunakan dalam suatu situasi tertentu. Gaya komunikasi merupakan cara penyampaian dan gaya bahasa yang baik. Gaya yang dimaksud sendiri dapat bertipe verbal yang berupa kata-kata atau nonverbal berupa vokalik, bahasa badan, penggunaan waktu, dan penggunaan ruang dan jarak (Widjaja, 2000:57).

Pengalaman membuktikan bahwa gaya komunikasi sangat penting dan bermanfaat karena akan memperlancar proses komunikasi dan menciptakan hubungan yang harmonis. Gaya komunikasi terdiri dari sekumpulan perilaku komunikasi yang dipakai untuk mendapatkan respon atau tanggapan tertentu dalam situasi tertentu pula. Kesesuaian dari satu gaya komunikasi yang digunakan, bergantung pada maksud dari pengirim (sender) dan harapan dari penerima (receiver).

Gaya komunikasi dipengaruhi situasi bukan kepada tipe seseorang, gaya komunikasi bukan tergantung pada tipe seseorang melainkan kepada situasi yang dihadapi. Setiap orang akan menggunakan gaya komunikasi yang berbeda-beda ketika mereka sedang gembira, sedih, marah, tertarik, atau bosan. Begitu juga dengan seseorang yang berbicara dengan sahabat baiknya, orang yang baru dikenal dan dengan anak-anak akan berbicara dengan gaya yang berbeda. Selain itu gaya yang digunakan dipengaruhi oleh banyak faktor, gaya komunikasi adalah sesuatu yang dinamis dan sangat sulit untuk ditebak. Sebagaimana budaya, gaya komunikasi adalah sesuatu yang relatif.

Sedangkan gaya komunikasi (Hariyana, 2009:14-18) yang menjadi acuan dalam penelitian ini sendiri ada enam yaitu; Pertama, the controlling style; Gaya komunikasi yang bersifat mengendalikan ini, ditandai dengan 
adanya satu kehendak atau maksud untuk membatasi, memaksa dan mengatur perilaku, pikiran dan tanggapan orang lain. Orang-orang yang menggunakan gaya komunikasi ini dikenal dengan nama komunikator satu arah atau one-way communications. Pihak-pihak yang memakai controlling style of communication ini, lebih memusatkan perhatian kepada pengiriman pesan dibanding upaya mereka untuk berharap pesan. Mereka tidak mempunyai rasa ketertarikan dan perhatian pada umpan balik, kecuali jika umpan balik atau feedback tersebut digunakan untuk kepentingan pribadi mereka. Para komunikator satu arah tersebut tidak khawatir dengan pandangan negatif orang lain, tetapi justru berusaha menggunakan kewenangan dan kekuasaan untuk memaksa orang lain mematuhi pandangan-pandangannya. Pesan-pesan yag berasal dari komunikator satu arah ini, tidak berusaha 'menjual' gagasan agar dibicarakan bersama namun lebih pada usaha menjelaskan kepada orang lain apa yang dilakukannya. The controlling style of communication ini sering dipakai untuk mempersuasi orang lain supaya bekerja dan bertindak secara efektif, dan pada umumnya dalam bentuk kritik. Namun demkian, gaya komunikasi yang bersifat mengendalikan ini, tidak jarang bernada negatif sehingga menyebabkan orang lain memberi respons atau tanggapan yang negatif pula.

Kedua, the equalitarian style; Aspek penting gaya komunikasi ini ialah adanya landasan kesamaan. The equalitarian style of communication ini ditandai dengan berlakunya arus penyebaran pesan-pesan verbal secara lisan maupun tertulis yang bersifat dua arah (two-way traffic of communication). Dalam gaya komunikasi ini, tindak komunikasi dilakukan secara terbuka. Artinya, setiap anggota organisasi dapat mengungkapkan gagasan ataupun pendapat dalam suasana yang rileks, santai dan informal. Dengan suasana yang demikian, memungkinkan setiap anggota organisasi mencapai kesepakatan dan pengertian bersama. Orang-orang yang menggunakan gaya komunikasi yang bermakna kesamaan ini, adalah orang-orang yang memiliki sikap kepedulian yang tinggi serta 
kemampuan membina hubungan yang baik dengan orang lain baik dalam konteks pribadi maupun dalam lingkup hubungan kerja. The equalitarian style ini akan memudahkan tindak komunikasi dalam organisasi, sebab gaya ini efektif dalam memelihara empati dan kerja sama, khususnya dalam situasi untuk mengambil keputusan terhadap suatu permasalahan yang kompleks. Gaya komunikasi ini pula yang menjamin berlangsungnya tindakan share atau berbagi informasi di antara para anggota dalam suatu organisasi.

Ketiga, structuring style; Gaya komunikasi yang berstruktur ini, memanfaatkan pesan-pesan verbal secara tertulis maupun lisan guna memantapkan perintah yang harus dilaksanakan, penjadwalan tugas dan pekerjaan serta struktur organisasi. Pengirim pesan (sender) lebih memberi perhatian kepada keinginan untuk mempengaruhi orang lain dengan jalan berbagi informasi tentang tujuan organisasi, jadwal kerja, aturan dan prosedur yang berlaku dalam organisasi tersebut. Stogdill dan Coons dari The Bureau of Business Research of Ohio State University, menemukan dimensi dari kepemimpinan yang efektif, yang mereka beri nama struktur inisiasi atau initiating structure. Stogdill dan Coons menjelaskan mereka bahwa pemrakarsa (initiator) struktur yang efisien adalah orang-orang yang mampu merencanakan pesan-pesan verbal guna lebih memantapkan tujuan organisasi, kerangka penugasan dan memberikan jawaban atas pertanyaan-pertanyaan yang muncul.

Keempat, the dynamic style; Gaya komunikasi yang dinamis ini memiliki kecenderungan agresif, karena pengirim pesan atau sender memahami bahwa lingkungan pekerjaannya berorientasi pada tindakan (action-oriented). The dynamic style of communication ini sering dipakai oleh para juru kampanye ataupun supervisor yang membawa para wiraniaga (salesmen atau saleswomen). Tujuan utama gaya komunikasi yang agresif ini adalah mestimulasi atau merangsang pekerja atau karyawan untuk bekerja dengan lebih cepat dan lebih baik. Gaya komunikasi ini cukup 
efektif digunakan dalam mengatasi persoalan-persoalan yang bersifat kritis, namun dengan persyaratan bahwa karyawan atau bawahan mempunyai kemampuan yang cukup untuk mengatasi masalah yang kritis tersebut.

Kelima, the relinguishing style; Gaya komunikasi ini lebih mencerminkan kesediaan untuk menerima saran, pendapat ataupun gagasan orang lain, daripada keinginan untuk memberi perintah, meskipun pengirim pesan (sender) mempunyai hak untuk memberi perintah dan mengontrol orang lain. Pesan-pesan dalam gaya komunikasi ini akan efektif ketika pengirim pesan atau sender sedang bekerja sama dengan orang-orang yang berpengetahuan luas, berpengalaman, teliti serta bersedia untuk bertanggung jawab atas semua tugas atau pekerjaan yang dibebankannya.

Keenam, the withdrawal style; Akibat yang muncul jika gaya ini digunakan adalah melemahnya tindak komunikasi, artinya tidak ada keinginan dari orang-orang yang memakai gaya ini untuk berkomunikasi dengan orang lain, karena ada beberapa persoalan ataupun kesulitan antarpribadi yang dihadapi oleh orang-orang tersebut.

Dalam deskripsi yangkongkrit adalah ketika seseorang mengatakan: "Saya tidak ingin dilibatkan dalam persoalan ini". Pernyataan ini bermakna bahwa ia mencoba melepaskan diri dari tanggung jawab, tetapi juga mengindikasikan suatu keinginan untuk menghindari berkomunikasi dengan orang lain. Oleh karena itu, gaya ini tidak layak dipakai dalam konteks komunikasi organisasi.

Gambaran umum yang diperoleh dari uraian di atas adalah bahwa the equalitarian style of communication merupakan gaya komunikasi yang ideal. Sementara tiga gaya komunikasi lainnya: structuring, dynamic dan relinguishing dapat digunakan secara strategis untuk menghasilkan efek yang bermanfaat dalam berkomunikasi, dan dua gaya komunikasi terakhir: controlling dan withdrawal yang mempunyai kecenderungan menghalangi berlangsungnya interaksi yang bermanfaat. Dari enam gaya komunikasi 
tersebut akan dijadikan sebagai acuhan dan landasan teori dalam penelitian ini, karena penelitian ini akan menganalisa gaya komunikasi masyarakat pesisir Kecamatan Wedung Kabupaten Demak apabila berkomunikasi dengan masyarakat sesama pesisir wilayah Wedung, masyarakat luar wilayah Kecamatan Wedung, dan turis (wisatawan).

\section{Metode Penelitian}

Penelitian ini menggunakan pendekatan etnografi. Metode penelitian etnografi termasuk dalam metode penelitian kualitatif. Sebagaimana menurut Emzir (2012:18) etnografi adalah ilmu penulisan tentang suku bangsa, menggunakan bahasa yang lebih kontemporer, Etnografi dapat diartikan sebagai penulisan tentang kelompok budaya. Menurut Ary, dkk (2010:459) etnografi adalah studi mendalam tentang perilaku alami dalam sebuah budaya atau seluruh kelompok sosial. Dalam pendekatan etnografi penelitian ini adalah peneliti mengamati orang (subyek penelitian) dengan cara berinteraksi langsung bersama dalam keadaan wajar dan dengan berusaha menilai gaya komunikasi, gaya hidup dan kebudayaannya. Teknik pengumpulan data menggunakan observasi, wawancara dan dokumentasi. Keabsahan data menggunakan triangulasi sumber.

Penelitian ini mengambil lokasi di Kecamatan Wedung yang terdiri dari 20 Desa, maka penulis menggunakan cluster sampling (area sampling), sehingga hanya mengambil 7 (tujuh) desa yaitu Desa Babalan, Bungo, Jetak, Kedungkarang, Kedungmutih, Kendalasem dan Wedung yang lebih dekat dengan laut (pesisir).

\section{Budaya dan Karakteristik Masyarakat Pesisir Kecamatan Wedung}

Karakteristik masyarakat pesisir berbeda dengan karakterisik masyarakat agraris atau petani. Dari segi penghasilan, petani mempunyai pendapatan yang dapat dikontrol karena pola panen yang terkontrol sehingga hasil pangan atau ternak yang mereka miliki dapat ditentukan untuk mencapai hasil pendapatan yang mereka inginkan. Berbeda halnya 
dengan masyarakat pesisir yang mata pencahariannya didominasi dengan nelayan. Nelayan bergelut dengan laut untuk mendapatkan penghasilan, maka pendapatan yang mereka inginkan tidak bisa dikontrol. Nelayan menghadapi sumber daya yang bersifat open acces dan beresiko tinggi. Hal tersebut menyebabkan masyarakat pesisir sepeti nelayan memiliki karakter yang tegas, keras, dan terbuka (Satria, 2002:27).

Selain itu, karakteristik masyarakat pesisir dapat dilihat dari beberapa aspek diantaranya: aspek pengetahuan, kepercayaan (teologis), dan posisi nelayan sosial. Dilihat dari aspek pengetahuan; masyarakat pesisir mendapat pengetahuan dari warisan nenek moyangnya misalnya: untuk melihat kalender dan penunjuk arah maka nelayan menggunakan rasi bintang. Sementara, dilihat dari aspek kepercayaan; masyarakat pesisir masih menganggap bahwa laut memiliki kekuatan magic sehingga mereka masih sering melakukan adat pesta laut atau sedekah laut. Namun, dewasa ini sudah ada dari sebagian penduduk yang tidak percaya terhadap adatadat seperti pesta laut tersebut. Mereka hanya melakukan ritual tersebut sebagai formalitas semata. Begitu juga dengan posisi nelayan sosial pada umumnya, nelayan tergolong kasta rendah.

Kehidupan sosial budaya masyarakat pesisir dan pulau-pulau kecil di Indonesia sangatlah beragam. Perkembanagan sosial budaya ini secara langsung maupun tidak langsung dipengaruhi oleh faktor alam.

Adat istiadat suku yang bermukim di wilayah pesisir dan pulaupulau kecil sangatlah beragam. Di beberapa tempat sering dijumpai adanya budaya pengaturan lahan laut atau sering disebut Hak ulayat laut. Aturan-aturan semacam ini merupakan satu kearifan lokal yang perlu dihargai sesuai dengan UUD 1945 Pasal 18B ayat 2 yang disebutkan bahwa Negara mengakui dan menghormati kesatuan-kesatuan masyarakat hukum adat beserta hak-hak tradisionalnya sepanjang hidup dan sesuai dengan perkembangan masyarakat dan prinsip Negara Kesatuan Republik Indonesia, yang diatur dengan Undang-Undang. 
Kebudayaan masyarakat pesisir dapat diartikan sebagai keseluruhan pengetahuan atau sistem kognisi yang ada dan berkembang pada masyarakat pesisir, yang isinya adalah perangkat-perangkat model pengetahuan yang secara selektif dapat digunakan untuk memahami dan menginterpretasi lingkungan yang dihadapi untuk mendorong dan menciptakan kelakuan-kelakuan yang diperlukan.

Masyarakat pesisir memerlukan bentuk kegiatan nyata yang dapat membangun ekonomi mereka tanpa menghilangkan kultur dan karakteristik dari masyarakat pesisir tersebut. Maka diperlukan bentuk kegiatan yang berbasis masyarakat. Berdasarkan Undang-Undang no.22 tahun 1999 tentang desentralisasi dan otonomi daerah yang memberikan wewenang kepada daerah untuk mengurus sendiri segala urusan daerahnya. Begitu juga dengan wilayah pesisir, ketua masyarakat atau kepala suku dapat bekerjasama dengan penduduk untuk mengurus pesisir dan lautnya sesuai dengan adat mereka.

Tradisi masyarakat pesisir sangat kental dengan aktivitas bahari, jauh sebelum teknologi mesin modern digunakan pada perahu-perahu nelayan. Bagi masyarakat daerah pesisir, menangkap ikan dengan cara yang tradisional selain untuk melestarikan budaya pendahulu juga dianggap sebagai cara yang tepat untuk tetap bisa bersahabat dengan alam sekitar yang telah menjadi tempat penghasilan kehidupan nelayan.

Jika secara demografi, masyarakat pesisir dianggap berkarakter keras, tegas dan tidak mudah diatur menjadi sebuah ciri masyarakat pesisir dalam berinteraksi dan berkomunikasi dengan orang lain. Tentunya, masyarakat pesisir juga mempunyai gaya atau model sendiri dalam berkomunikasi dengan orang lain, maupun orang luar wilayah pesisir. Walaupun demikian, masyarakat pesisir tetap menjadi bagian dari masyarakat Indonesia yang masih mempertahankan budaya dan tradisi pesisiran.

Kecamatan Wedung merupakan salah satu Kecamatan di Kabupaten Demak. Sebelah utara wilayah ini berbatasan dengan Kabupaten Je- 
para, sebelah timur berbatasan dengan Kecamatan Mijen, sebelah selatan berbatasan dengan Kecamatan Bonang, serta sebelah barat berbatasan dengan Laut Jawa. Jarak terjauh dari barat ke timur adalah sepanjang $20 \mathrm{~km}$.

Secara administratif Kecamatan Wedung terdiri dari 20 desa, 26 dusun serta 107 RW dan 434 RT. Seluruh desa di Kecamatan Wedung yaitu: Desa Wedung, Ngawen, Ruwit, Kenduren, Buko, Mandung, Berahan Kulon, Berahan Wetan, Bungo, Tempel, Jetak, Jungsemi, Jungpasir, Mutih Wetan, Mutih Kulon, Tedunan, Kendalasem, Kedungkarang, Kedungmutih dan Babalan. Seluruh desa di Kecamatan Wedung sudah termasuk klasifikasi swasembada. Jumlah perangkat yang telah terisi adalah Kepala Desa sejumlah 20 orang, sekretaris desa 13 orang, kepala dusun 11 orang, kepala kaur 81 orang dan pembantu kaur 81 orang.

Jarak Kecamatan Wedung ke desa terjauh adalah ke Desa Kedung Mutih dengan jarak $20 \mathrm{~km}$ dan jarak terdekat dengan Desa Ngawen yaitu $5 \mathrm{~km}$. Sedangkan jenis tanah di wilayah Kecamatan Wedung adalah tanah Asosilasi alavial yaitu kelabu dan sebagian tanah pantai. Jarak dari permukaan air laut adalah 0-3 meter.

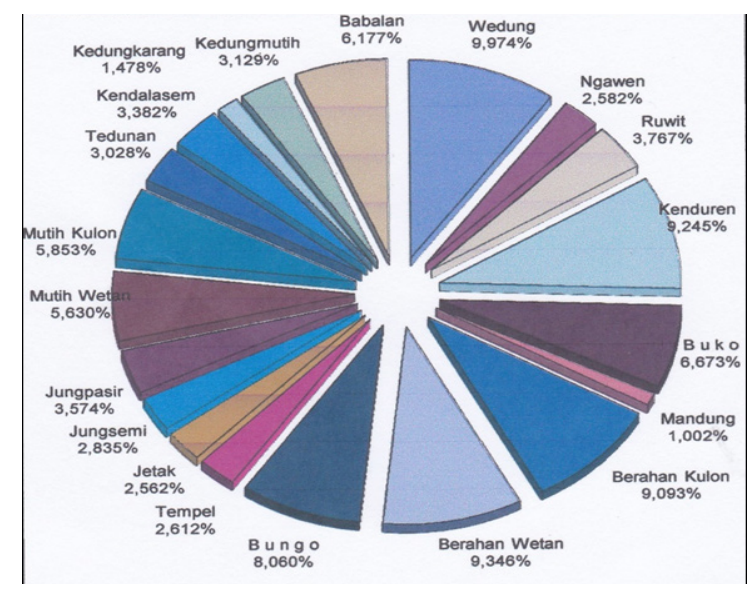

Gambar 1. Luas Wilayah Kecamatan Wedung Menurut Desa

Tahun 2014

(Sumber: Kecamatan Wedung dalam Angka 2015) 
Jumlah penduduk Kecamatan Wedung berdasarkan hasil Registrasi Penduduk 2014 adalah sebanyak 72.722 orang, terdiri atas 35.886 lakilaki dan 36.836 perempuan. Jumlah penduduk ini bertambah sebanyak 172 orang atau sekitar 0,24 persen dari tahun sebelumnya.

Berdasarkan hasil observasi peneliti, wilayah Kecamatan Wedung terbilang daerah yang minim fasilitas umum, seperti ATM, mini market, SPBU dan transportasi umum. Sebagian besar di wilayah Kecamatan Wedung, masih menggunakan transportasi laut yaitu perahu untuk menghubungkan desa satu dengan desa yang lain. Selain itu, transportasi laut menjadi salah satu transportasi utama di wilayah Kecamatan Wedung untuk mengantarkan masyarakat berangkat kerja dan mengangkut barang-barang.

Selain itu, wilayah Kecamatan Wedung merupakan wilayah pesisir dengan jumlah penduduk yang padat dan mayoritas penduduknya beragama Islam, karena kepadatan penduduk yang tidak diimbangi dengan fasilitas menjadikan wilayah pesisir Kecamatan Wedung menjadi daerah yang minus dan terkesan kumuh. Hal ini dapat dilihat dari kurang dan langkanya air bersih, tempat tinggal yang kotor dan sistem peternakan yang berdampingan dengan tempat tinggal.

Jika melihat kondisi lingkungan dan masyarakat pesisir Kecamatan Wedung, tentunyan gaya komunikasi masyarakat pesisir bisa juga berbeda dengan gaya komunikasi masyarakat perkotaan. Gaya komunikasi pada dasarnya dipengaruhi oleh situasi, bukan kepada tipe seseorang, gaya komunikasi bukan tergantung pada tipe seseorang melainkan kepada situasi yang dihadapi. Setiap orang akan menggunakan gaya komunikasi yang berbeda-beda ketika mereka sedang gembira, sedih, marah, tertarik, atau bosan. Begitu juga dengan seseorang yang berbicara dengan sahabat baiknya, orang yang baru dikenal dan dengan anak-anak akan berbicara dengan gaya yang berbeda. Selain itu gaya yang digunakan dipengaruhi oleh banyak faktor, gaya komunikasi adalah sesuatu yang dinamis dan 
INJECT: Interdisciplinary Journal of Communication, Vol.2, No.1, Juni 2017: h. 53-76

sangat sulit untuk ditebak. Sebagaimana budaya, gaya komunikasi adalah sesuatu yang relatif.

Berdasarkan penjelasan di atas, menunjukkan bahwa gaya komunikasi ditentukan dan dipengaruhi oleh situasi dan kondisi dimana seseorang berada. Jika dikaitkan dengan masyarakat pesisir Kecamatan Wedung yang secara geografis merupakan masyarakat yang berdomisili di pesisir pantai dan umumnya mempunyai plurarisme budaya, sehingga masyarakat pesisir cenderung agresif karena kondisi lingkungan pesisir yang panas dan terbuka, selain itu keluarga nelayan mudah diprovokasi (dipengaruhi), dan salah satu kebiasaan dikalangan nelayan (masyarakat pesisir) adalah karena kemudahan mendapatkan uang menjadikan hidup mereka lebih konsumtif. Secara umum dapat dikatakan bahwa masyarakat pesisir memiliki karakter yang keras dan tidak mudah diatur (Kusnadi, 2002:36).

Kondisi geografis inilah yang menjadikan masyarakat pesisir cenderung keras karakternya dan mempengaruhi gaya komunikasinya. Hal ini nampak jika masyarakat pesisir Kecamatan Wedung sedang berbicara dengan orang lain. Suara yang dikeluarkan sangat lantang dan tegas. Sehingga berdampak pada respon dari lawan bicara (orang yang mendengarkan) juga akan berbeda dalam menanggapinya.

Menurut hasil obervasi dan interaksi penulis selama melakukan pengamatan di lokasi penelitian dan berinteraksi dengan masyarakat Kecamatan Wedung ditemukan data bahwa dalam berkomunikasi masyarakat pesisir Kecamatan Wedung terbilang baik dan sopan. Jika, berkomunikasi dengan turis (wisatawan) dan orang di luar wilayah Kecamatan Wedung respon yang diberikan dan cara bertutur kata masyarakat pesisir Kecamatan Wedung sangat baik, sopan dan ramah. Bahasa yang digunakan adalah bahasa Jawa Krama dan Jawa Ngoko. Namun, jika dilihat dari gesture (raut wajah dan pandangan mata) terlihat seperti orang ingin tahu dan mencari tahu, muncul rasa penasaran dan bertanya-tanya. Jadi, rasa ingin tahu 
masyarakat pesisir Kecamatan Wedung sangat tinggi terhadap sesuatu yang baru dan seseorang yang baru ditemuinya. Walaupun demikian, tidak selamanya dan semua respon dan komunikasi masyarakat pesisir Kecamatan Wedung baik dan sopan, terkadang mereka juga bersikap kasar, acuh dan tidak mau tahu bahkan tidak memberi respon apapun jika diajak berkomunikasi dan berhadapan dengan orang asing atau orang luar wilayahnya.

Komunikasi masyarakat pesisir Kecamatan Wedung baik jika dengan orang asing dan orang luar wilayahnya. Namun, jika orang asing atau orang luar wilayah Kecamatan Wedung tersebut sudah menetap atau tinggal berhari-hari di wilayah Kecamatan Wedung dan masyarakat sekitar sudah mengetahui sifat dan karakter jelek orang asing tersebut, maka masyarakat pesisir Kecamatan Wedung akan langsung mengambil sikap tidak suka dan membatasi pergaulan (interaksi sosialnya).

Komunikasi yang dilakukan oleh masyarakat pesisir Kecamatan Wedung pada dasarnya tergantung pada komunikator (orang yang menyampaikan pesan). Jika komunikatornya memulai komunikasi dengan baik dan menggunakan bahasa yang halus (jawa krama/krama inggil) maka masyarakat pesisir Kecamatan Wedung juga akan menanggapi dengan baik dan halus. Begitu sebaliknya, jika dari awal berkomunikasi menggunakan bahasa yang tidak sopan dan kasar, masyarakat pesisir Kecamatan Wedung juga akan merespon dengan kasar pula.

Pada dasarnya masyarakat pesisir Kecamatan Wedung dalam berkomunikasi terbilang baik dan sopan, walaupun masih ditemukan respon yang tidak baik dan acuh. Namun, ditemukan hanya pada beberapa orang saja, dan hal ini bisa dikarenakan pendidikan dan faktor psikologis yang berbeda-beda.

Dari segi gaya komunikasi, masyarakat pesisir Kecamatan Wedung cenderung menggunakan gaya komunikasi the equalitarian style. Gaya komunikasi ini bersifat dua arah (two-way traffic of communication) dan 
dilakukan secara terbuka. Artinya masyarakat pesisir Kecamatan Wedung dalam berkomunikasi lebih suka dan cenderung dua arah sehingga ada feedback (respon) baik dari komunikator dan komunikan. Pada dasarnya masyarakat pesisir Kecamatan Wedung mempunyai sifat terbuka dalam komunikasi, namun hal ini jika ditunjang dengan kondisi dan situasi yang baik, rileks, santai dan informal. Dengan kondisi demikian, masyarakat pesisir Kecamatan Wedung dalam berkomunikasi lebih dapat memahami pesan yang disampaikan komunikator dengan baik, terjadinya kesamaan makna serta menjalin hubungan dengan baik, sehingga dapat memelihara empati dan kerjasama.

Seperti telah dijelaskan penulis di atas, bahwa dalam berkomunikasi masyarakat pesisir Kecamatan Wedung lebih tergantung pada komunikatornya. Hal ini dapat menjadikan komunikasi yang terjalin baik dan tidak, jika komunikator pandai menentukan sikap dan situasi yang tepat serta cara penyampaian pesan yang baik dan sopan, maka masyarakat pesisir Kecamatan Wedung sebagai komunikannya juga akan menerima dengan baik dan feedback (respon) yang baik pula.

Selanjutnya, selain gaya komunikasi the equalitarian style, ditemukan pula masyarakat pesisir Kecamatan Wedung dalam berkomunikasi sering menggunakan gaya komunikasi the relinguishing style. Gaya komunikasi ini mencerminkan kesediaan untuk menerima saran, pendapat atau gagasan dari orang lain. Jadi, sebagian masyarakat pesisir Kecamatan Wedungjuga tidak menutup diri dalam berkomunikasi dan dapat menerima pendapat serta saran dari orang lain atau penduduk luar wilayah pesisir Kecamatan Wedung. Hal ini biasanya terjadi jika masyarakat pesisir Kecamatan Wedung berkomunikasi dengan orang-orang yang berpengetahuan luas, berengalaman dan berpendidikan tinggi. Namun hal ini juga diimbangi dengan tindakan nyata.

Dari beberapa pengamatan dan hasil wawancara penulis terhadap beberapa masyarakat Kecamatan Wedung, menunjukkan bahwa masya- 
rakat pesisir Kecamatan Wedung mulai mengalami perkembangan dan kemajuan taraf hidup. Hal ini menunjukkan bahwa masyarakat pesisir Kecamatan Wedung adalah masyarakat pesisir yang sudah mulai menerima modernisasi, sehingga dalam kesehariannya mereka banyak berinterkasi dengan masyarakat pendatang dan masyarakat kota. Hal ini dibuktikan dengan mayoritas masyarakat pesisir Kecamatan Wedung sudah terbiasa dan bisa berbahasa Jawa krama dan krama inggil. Hal ini mempengaruhi dalam berkomunikasi dengan masyarakat luar wilayah Kecamatan Wedung terutama masyarakat kota.

Walaupun masih ada beberapa aturan-aturan yang dipegang teguh oleh masyarakat pesisir Kecamatan Wedung, contohnya: orang perempuan dilarang keluar malam setelah pukul 21.00 WIB. Aturan ini sudah ada dan dipegang kuat oleh masyarakat pesisir Kecamatan Wedung, sehingga tidak ada perempuan pesisir Kecamatan Wedung yang keluar malam hari. Prinsip bagi perempuan-perempuan pesisir Kecamatan Wedung jika malam hari adalah waktunya istirahat, karena esok pagi masih banyak pekerjaan yang harus dilakukan yaitu membantu suami menyiapkan pekerjaan terutama yang suaminya menjadi nelayan dan harus menyiapkan bekal untuk melaut, mengasuh anak, dan menyiapkan keperluan anak-anak yang akan sekolah.

Hal ini akhirnya, menjadi ciri antara penduduk asli pesisir Wedung dengan penduduk pendatang. Karena, jika ada perempuan keluar malam hari berarti itu bukan perempuan penduduk asli Kecamatan Wedung.

Makna dari aturan perempuan tidak boleh keluar malam hari di wilayah Kecamatan Wedung adalah karena perempuan mempunyai beban pekerjaan yang lebih berat dibanding laki-laki, selain membantu suami bekerja, contohnya seperti istri nelayan; harus membantu mengemasi ikan, menjemur sampai menjualnya di pasar dan menyiapkan peralatan yang akan dibawa untuk melaut malamnya. Selain itu, perempuan pesisir Kecamatan Wedung juga harus merawat dan mengurus anak-anak serta 
menyelesaikan pekerjaan rumah lainnya, sehingga perempuan pesisir Kecamatan Wedung harus tidur duluan (tidak boleh tidur malam-malam) karena besok pagi masih ada pekerjaan lain yang harus dikerjakan lagi.

Jadi dapat disimpulkan masyarakat pesisir Kecamatan Wedung dalam berkomunikasi dengan masyarakat sesama pesisir, turis (wisatawan) dan masyarakat luar wilayah pesisir Kecamatan Wedung terjalin dengan baik dan sopan, walaupun terkadang bahasa dan nada suara yang digunakan terdengar kasar dan keras, hal ini tidak terlepas dari faktor geografis masyarakat pesisir. Selain itu, penggunaan bahasa dalam berkomunikasi yang dilakukan masyarakat pesisir Kecamatan Wedung adalah bahasa jawa (jawa krama dan jawa ngoko). Gaya komunikasi yang digunakan adalah the equalitarian style dan the relinguishing style.

Dari gaya komunikasi masyarakat pesisir dan bahasa yang digunakan dalam berkomunikasi dapat menunjukkan bahwa masyarakat pesisir masih memegang teguh tradisi dan budaya pesisiran yang ada selama ini di wilayahnya. Hal itu juga nampak pada beberapa tradisi-tradisi yang dilakukan masyarakat pesisir sebagai wujud komunikasi mereka terhadap Tuhan, lingkungan (sumber daya alam) dan masyarakatnya.

Gaya komunikasi maupun adat istiadat yang melekat pada masyarakat pesisir Kecamatan Wedung menunjukkan bahwa mereka mempunyai speech codes. Merujuk pada speech codes theory yang dipublikasikan oleh Gerry Philipsen (dalam Griffin, 2003:448-449) bahwa setiap komunitas mempunyai ciri khas yang membedakannya dengan komunitas lain salah satunya dari kode berbicara dalam berkomunikasi. Hal ini jugalah yang membedakan masyarakat pesisir Kecamatan Wedung sebagai masyarakat pesisir Jawa tengah dengan masyarakat pesisir Jawa timur atau Jawa barat. Dari gaya komunikasi masyarakat pesisir Kecamatan Wedung menunjukkan bahwa sebenarnya masyarakat pesisir Kecamatan Wedung sudah mulai berkembang dan terbuka dalam menerima informasi dan perubahan zaman. Gaya komunikasi yang cenderung dua arah dan 
terjadi feedback serta adanya speech codes dalam berkomunikasi sudah menjadi bukti keberadaan komunitas pesisir Kecamatan Wedung dan terjadinya arus pertukaran informasi. Oleh sebab itu dapat disimpulkan bahwa masyarakat pesisir Kecamatan Wedung adalah komunitas yang mampu menerima informasi dari luar dan dapat berkomunikasi dengan masyarakat di luar wilayahnya.

\section{Simpulan}

Dalam penelitian ini dapat disimpulkan sebagaimana bahwa gaya komunikasi masyarakat pesisir dalam berkomunikasi dengan sesama masyarakat pesisir, masyarakat luar wilayah Kecamatan Wedung dan turis (wisatawan) adalah the equalitarian style. Gaya komunikasi yang bersifat dua arah (two-way traffic of communication) dan dilakukan secara terbuka. Artinya masyarakat pesisir Kecamatan Wedung dalam berkomunikasi lebih suka dan cenderung dua arah sehingga ada feedback (respon) baik dari komunikator dan komunikan. Pada dasarnya masyarakat pesisir Kecamatan Wedung mempunyai sifat terbuka dalam berkomunikasi, namun hal ini jika ditunjang dengan kondisi dan situasi yang baik, rileks, santai dan informal.

Selain the equalitarian style masyarakat pesisir Kecamatan Wedung juga menggunakan gaya komunikasi the relinguishing style. Gaya komunikasi ini mencerminkan kesediaan untuk menerima saran, pendapat atau gagasan dari orang lain. Jadi, sebagian masyarakat pesisir Kecamatan Wedung juga tidak menutup diri dalam berkomunikasi dan dapat menerima pendapat serta saran dari orang lain atau penduduk luar wilayah pesisir Kecamatan Wedung. 
INJECT: Interdisciplinary Journal of Communication, Vol.2, No.1, Juni 2017: h. 53-76

\section{Daftar Pustaka}

Badan Pusat Statistik (BPS) Kabupaten Demak. 2014. Kecamatan Wedung dalam Angka.

Geertz, Clifford. 1981. Abangan, Santri, Priyayi dalam Masyarakat Jawa. Jakarta: Pustaka Jaya.

Griffin, EM. 2003. A First Look at Communication Theory. Fifth Edition. Newyork: Mc Graw - Hill.

Hariyana. 2009. Komunikasi dalam Organisasi. Makalah Fakultas Ilmu Sosial dan Politik Universitas Indonesia.

Koentjaraningrat. 1993. Metode-metode Penelitian Masyarakat. Jakarta:

Gramedia Pustaka Utama.

- 1993. Kebudayaan, Mentalitas dan Pembangunan. Jakarta:

Gramedia Pustaka Utama.

Kusnadi. 2002. Konflik Sosial Nelayan. Yogyakarta: LKiS.

Muhaimin. 2001. Islam dalam Bingkai Budaya Lokal, Potret dari Cirebon.

Jakarta: Logos.

Ranjabar, Jacobus. 2006. Sistem Sosial Budaya Indonesia Suatu Pengantar. Bandung: Ghalia Indonesia.

Satria. 2002. Pengantar Sosiologi Masyarakat Pesisir. Jakarta: Cidesindo.

Sobur, Alex. 2004. Semiotika Komunikasi. Bandung: Remaja Rosdakarya. Syarif, Makmur. 2008. Pemberdayaan Sumber Daya Manusia dan Efektivitas Organisasi. Jakarta: PT Raja Grafindo Persada.

Tasmuji, dkk. 2011. Ilmu Alamiah Dasar, Ilmu Sosial Dasar, Ilmu Budaya Dasar. Surabaya: IAIN Sunan Ampel Press.

Widjaja, H.A.W. 2000. Ilmu Komunikasi Pengantar Studi. Jakarta: PT. Rineka Cipta. 